\title{
NUAK Family SNF1-Like Kinase 1
}

National Cancer Institute

\section{Source}

National Cancer Institute. NUAK Family SNF1-Like Kinase 1. NCI Thesaurus. Code C126573.

NUAK family SNF1-like kinase 1 (661 aa, 74 kDa) is encoded by the human NUAK1 gene.

This protein plays a role in protein phosphorylation, which regulates DNA damage

response, apoptosis, cell adhesion, cellular senescence, and cell proliferation. 